\title{
The Essence of Settlement of Property Crimes : Diversion Through Restorative Justice
}

\author{
Abdurrifai $^{1}$ Musakkir $^{2}$ Muhadar $^{2}$ Haeranah $^{3}$ \\ 1.Doctoral Student, Faculty of Law, Hasanuddin University, Indonesia \\ 2. Professor of Law, Faculty of Law, Hasanuddin University, Indonesia \\ 3. Lecturer, Faculty of Law, Hasanuddin University, Indonesia
}

\begin{abstract}
Settlement of property crimes through diversion with the restorative justice approach is an effort to resolve problems involving all parties, including perpetrators, victims, families, law enforcers and third parties. This settlement process puts forward deliberation to reach a consensus where all parties involved can each express their intentions and desires so that the settlement of criminal acts of property can create a sense of justice, benefit and certainty.
\end{abstract}

Keywords: Property Crimes, Diversion, Restorative Justice.

DOI: $10.7176 / \mathrm{JLPG} / 101-09$

Publication date:September $30^{\text {th }} 2020$

\section{A. Introduction}

Law as a rule that governs human life from birth to death. One of the duties of law is to protect the interests of humans both individually and in groups or in society, the law exists to resolve conflicts that occur or may occur in society, both individually and in groups. The law regulates the governance of order so that society or individuals are protected by their rights and obligations, their dignity is maintained. So important is the law in a society that we know the adegium said by Marcus Tullius Cicero that "Ubi societas ibi ius, which means that where there is a society there is law"1, this means that law cannot exist if society does not exist and society is disorganized if the law does not present there, in other words that law and society cannot be separated.

Law can not be seen as something final (finite scheme), but the law must continue to move, change and follow the dynamics of human life. ${ }^{2}$ Legal relations and legal actions that exist or occur due to human interaction activities in sustaining life, and in fulfilling their daily needs, sometimes cause legal consequences that can result in both moral and material losses and to recover the said losses, both civil and criminal legal remedies must be taken. In the civil sector, for example, cases of Default and / or Unlawful Actions can be filed.

In law enforcement, especially in the civil sector, for example those originating from Defaults, it is very long and tiring both time and costs as a result of this, the injured party will take a shortcut by taking criminal legal action, namely reporting to the Police with criminal acts of property such as embezzlement. as regulated in Article 372, fraud as regulated in Article 378 which is regulated in the Criminal Code (KUHP), because it is considered faster and has more power to suppress the perpetrator or the party causing the loss to settle the loss. raised. Solving problems or cases that have started from civil law acts to become criminal problems by reporting the problem to the Police is currently becoming a trend, and for this effort, law enforcement officials, in this case the Police, as the front guard in the criminal justice system, cannot refuse to deal with it. reports or disputes that occur. The investigator is obliged to handle it properly and correctly in accordance with the rules of law (procedure) in force, in accordance with the principles of material criminal law, if the investigator (police) has found sufficient initial evidence that the incident is a criminal event, it is difficult for the perpetrator to be free from criminal responsibility. This is where the professionalism of the Police (Investigators) as the leading law enforcement apparatus is tested by using the powers and instruments at their disposal. Law enforcement officials must understand the norms of civil law covered by the existing principle of freedom of contract and its existence on the basis of agreement, on the principle of balance and consensus, and norms of criminal law covered by the principle of prohibition, all of which have been regulated regarding what is prohibited or what should not be done and if violated then the offender or the perpetrator will be given or subject to criminal sanctions. These criminal law norms have a coercive power that can curb human rights.

Law enforcement is an activity to carry out or implement the law to maintain, regulate and guard the law so that it is carried out and enforced properly or according to its purpose and function. Laws need to be upheld so that human rights as individuals and as citizens are guaranteed and protected. In the law enforcement process, tactics and strategies for handling problems are needed appropriately so that it can realize the true objectives of law, namely order, maintaining and maintaining human and human dignity, in the law enforcement process, substantial

\footnotetext{
${ }^{1}$ Sadjijono. (2014). Hukum Antara Sollen dan Sein (Dalam Perspektif Praktek Hukum di Indonesia). Surabaya: Ubhara Press \& LaksBang PRESSIndo. p. 6

${ }^{2}$ Nur, R., \& Bakhtiar, H. S. (2020). The Imposition of Sanctions for Children. Hasanuddin Law Review, 6(2), $165-171$.
} 
truth (substantial justice) must be prioritized rather than procedural truth. procedural justice) which prioritizes procedures that sometimes deprive justice seekers of their rights. It is time for procedural truth or procedural justice to be renewed in order to fulfill a sense of justice, one of which is by reforming the law, especially in the field of criminal law, especially regarding the settlement of criminal acts of property.

Legal reform is needed because the times and changes in the human mindset in solving problems have changed, likewise existing laws are not adequate or are no longer in accordance with the development of community law and even lag behind legal practices in society, especially with values who grow and develop and who live in society. The reform of criminal law must be studied from a juridical, sociological and philosophical perspective, especially in relation to criminal or criminal sanctions, fines and settlement of cases. In the future, legal reform must also pay attention to the crystallized values in the Pancasila principles as the source of all sources of law and must color the legal system, namely the structure, substance and culture of the law. Through this system, the law will be able to achieve its objectives which are not only Justice, Benefit and Certainty, but more than that, namely upholding human dignity and humanity.

The concept of a criminal justice system in the future must pay attention to effectiveness and efficiency as well as economics related to criminal sanctions and the process of solving the case. The concept of criminal law that solely prioritizes punishment or retaliation has slowly begun to be abandoned and has entered a new era or a new phase, namely the reform of the criminal law system that leads to legal protection of victims by providing compensation and / or providing a deterrent effect to the perpetrator by charging compensation loss or even social work.

In principle, law enforcement of property crimes needs to be handled comprehensively, clearly, and decisively to protect victims, and at the same time provide education to the public that property crime is a violation of human rights, violates the rights of individual fellow humans, especially the right to property, violates the dignity of humans which should be upheld by anyone without exception. Law enforcement does not always have to be based on what the law says, but must pay attention to the principles and values that live, grow and develop in society, because in fact this is what is called a just law that can provide justice and benefits that lead to the maintenance. human dignity.

In relation to law enforcement on property crimes, it is necessary to think about alternative solutions to problems that provide legal protection to all related parties, namely victims and perpetrators by prioritizing justice, benefit and legal certainty.

For this reason, law enforcement must be adjusted to the progress and developments of the times, especially the purpose of punishment must change according to the developments and changes in question. The aim of punishment which was originally from retributive must be changed to restorative from retaliation to recovery or compensation or even with social work. Not all criminals have to be convicted, there are certain cases that need legal breakthroughs using the Diversion approach or concept through Restorative Justive as well as criminal acts against property, except theft by force, weighting and extortion with threats.

In principle, the application of diversion through restorative justice is a strategic step to carry out legal reform in the field of criminal law, especially in dealing with criminal property cases because it can reduce the burden on the state in financing the growing prisoners and the capacity of prisons or correctional institutions overcrowding, and what is more important is the realization of the principle of simple, fast and low cost (cheap).

To carry out legal reform, especially in criminal acts of property with the concept of diversion through the restorative justice approach, it must be done by changing the legal structure, namely by making connectivity and synergy between law enforcement agencies (Police, Attorney General's Office and Courts (Judges) and Correctional Institutions). By synergizing, it will result in maximum law enforcement in providing justice and benefit to humans, this is where the law functions and plays a role in protecting the whole human body and soul, which ultimately the law will maintain and protect human dignity, humanize humans. The substance of the law, in this case the laws and regulations (material and formal criminal law) must be made and designed for the benefit of law enforcement that provide or reflect the values of justice and non-legal benefits that injure human rights, laws that truly protect human rights. humans, who humanize humans, which ultimately aims to protect and maintain human dignity. Legal culture, in this case legal awareness, legal behavior, and the legal mindset of law enforcement officials and the community, must always be based on the law and for that know the law (know the law), obey the law, and obey the law (Know the law, obey the law, and Obey the Law) ${ }^{1}$. The structure, substance and culture of this law must run integrally, simultaneously and in parallel in order to create a just and useful law.

Settlement of property criminal cases using the concept of diversion with a restorative justice approach is not yet known or regulated in the Indonesian Criminal Code (KUHP) and for this it is necessary to make efforts to reform the law in the criminal law system, this is one model of legal system reform future crimes (ius costituendum), a concept of criminal law that is aspired to be in accordance with the character and spirit of society and Indonesian culture. This concept is actually and actually has been practiced by our society and has become a

\footnotetext{
${ }^{1}$ Muhadar, (2017), delivered his lecture material to the Doctor of Law Program in the Faculty of Law, Hasanuddin University Makassar
} 
value in social life when solving problems or disputes experienced by community members. These values have crystallized in Pancasila.

Diversion in principle does not eliminate criminal acts that have been committed by the perpetrator against the victim, but Diversion is only one way or action to change or divert the criminal process that is being pursued by a victim by using a familial approach through deliberation, consensus, peace while paying attention and restoring the rights of victims (restorative justice principle). In other words, Diversion is the transfer of the process from a case settlement process based on an integrated criminal justice system to an out-of-court case settlement process which can be carried out at the stage of Investigation by Investigators, Prosecution by Public Prosecutors and Examination in Courts by Judges, thus Diversion is a deviation from the integrated criminal justice system. In principle, this process does not eliminate the essence of criminal law which is "ultimum remedium", but is solely related to the effectiveness and efficiency of the application of ultimum remedium itself.

In the criminal justice system (Indonesian legal system) settlement with the concept of Diversion through the principle of restorative justice is regulated for the first time in Law No. 11 of 2012, while the criminal act of property has not been regulated in legislation (it has not become positive law and has become formal law), however, law enforcement officers have taken discretion by applying it at their respective stages, as in the investigation stage, there is a letter Head of the Indonesian Police Criminal Investigation Agency No. STR / 583 / VIII / 2012 concerning the Implementation of Restorative Justice, Circular of the Chief of the Indonesian National Police No. 8 of 2018 concerning the Implementation of Restorative Justice in Criminal Case Settlement, at the prosecution stage there is the Attorney General's Regulation No. PER-005 / A / JA / 01/2011 dated 12 January 2011 concerning Education and Training for Handling Crime of Children Against the Law, Batch I, II, and III and at the trial stage in court there is the Supreme Court Regulation No. 4 of 2018 concerning Guidelines for the Implementation of Diversion in the Juvenile Criminal Justice System, however it is not maximally implemented by law enforcement officials.

Indonesian people are accustomed and trained to solve problems by promoting consensus, peace and mutual respect and this is exactly the same concept adopted by restorative justice. Restorative justice focuses on justice and certainty between retributive and restitution, because restorative justice emphasizes the importance of the role or involvement of victims and community members and encourages perpetrators to be responsible to victims by recovering both material and immaterial losses and the victim's emotions by promoting dialogue, negotiation, and deliberation to reach consensus in solving problems or problems that occur using the concept of Diversion. Diversion will be achieved if there is forgiveness, sincerity, and peace from the victim which is preceded by an apology, admission of mistakes and willingness to compensate the perpetrator. One thing that needs to be remembered regarding this Diversion is, if the Diversion fails to be carried out, the law enforcement process through court channels will continue to use ordinary procedural law in accordance with the criminal procedural law (criminal justice system).

The concept of diversion through the principle of restorative justice is actually the transfer of the process of settlement of property crimes, which was originally carried out through the mechanism of the integrated criminal justice system, is changed or transferred to settlement of cases outside the court (outside the integrated criminal justice system) based on deliberation involving the victim, family victims, perpetrators or perpetrators' families, law enforcement officials and other third parties as mediators by emphasizing restoration to its original state, and not retaliation (imprisonment) so that peace and harmony can be created between the victim and the perpetrator and the community. With the concept of diversion through the principle of restorative justice, the victim feels satisfied and treated fairly because he is involved in the process of imposing sanctions and is also restored, the victim receives compensation according to his or her rights or returns the loss suffered and the perpetrator is aware and sorry for his actions and his dignity is maintained because he is not imprisoned physically.

For this reason, based on the previous description, this article will discuss the essence of the settlement of property crimes with the concept of Diversion through the Restorative Justice approach. This article is a normative legal research (doctrinal), which is a research that places law as a norm system building. The norm system in question is about the principles, norms, rules of legislation, court decisions, agreements and doctrines. ${ }^{1}$ Then an analysis is carried out to reach a conclusion and provide legal arguments by providing a prescription or assessment which is the core of normative legal research. ${ }^{2}$

\section{B. Analysis and Discussion}

1. The realization of legal justice for property crimes.

The highest goal of law is justice. Fair means doing everything in accordance with its proportions, By putting things proportionately means that justice is order and discipline, heresy is an act that violates the proportional principles of order and discipline. Like wearing shoes underneath and a hat on top of your head. The concept of

\footnotetext{
${ }^{1}$ Mukti Fajar \& Yulianto Achmad, (2010), Dualisme Penelitian Hukum Normatif \& Empiris, Yogyakarta: Pustaka Pelajar, p. 34

${ }^{2}$ I Made Pasek Diantha, 2016, Metodologi Penelitian Hukum Normatif Dalam Justifikasi Teori Hukum, Jakarta: Prenadamedia Group, p. 152 153
} 
justice is the same as the principle of scientific thinking which should be objective, empirical, and consistent, namely the relevance between statements and reality. ${ }^{1}$

In principle, the settlement of criminal acts is not solely resolved through mechanisms within the court but can also be carried out outside the court, especially in connection with diversion through the principle of restoratve justice. This can be understood from Eva Achjani Zulfa's statement in A.M. Syukri Akub and Sutiawati ${ }^{2}$ who stated that restorative justice in their correlation with the criminal justice system can be seen from the three models of the relationship between restorative justice and the criminal justice system as stated in The Vienna Declaration On Crime and Justice 10-17 April 2000, namely:

1. As part of the criminal justice system;

2. Outside the criminal justice system through other institutions / institutions outside the system;

3. Outside the criminal justice system by continuing to involve law enforcers.

It is a common opinion that the process of settlement of cases through courts with a criminal justice system based on KUHAP has not fully provided justice, benefits and even legal certainty, because the process and mechanism for resolving cases are convoluted, long, and expensive, not in accordance with the principles of criminal procedural law fast, simple, and low cost (cheap), the principle of equality before the law and the presumption of innocence, and what is certain is that the ultimate goal of the law enforcement process through the criminal justice system is to punish the perpetrators of criminal acts, even though in fact the punishment or conviction is not the only and not the end goal. The ultimate goal of the criminal process is to restore the psychological condition or character of the perpetrator of the crime to be better and even better so that he does not repeat his actions. This is in line with the opinion of Sanfrod H. Kadish as quoted by Kadri Husin and Budi Rizki Husin $^{3}$ who explained that:

"The criminal decision is a very big consequence. Criminalization is the highest level rather than a complex solution of a real criminal procedural law system, which aims at the end (the ultimate rationale) to shape people who have committed crimes to be useful and trustworthy. A criminal decision must be complete and contain what will be done to the convicted person, a criminal decision as a social impact only has meaning for individuals who risk their life and freedom ".

Often encountered the idea that every criminal case must be tried through the criminal justice mechanism and imprisoned as a retribution for the perpetrator's actions. To a certain extent, criminal punishment in the form of imprisonment can be an effective means of preventing crimes from occurring. However, in plain view it turns out that life in prisons in Indonesia still leaves homework, which has a negative impact on the treatment of prisoners / assisted citizens, even in certain correctional institutions it is one of the platforms for the proliferation of crime, including the existence of drug trafficking in prisons. ${ }^{4}$

To realize justice in the settlement of property crimes with the concept of diversion through restorative justice, there are several things that must be done, including:

1) there is a criminal act

2) There are losses and compensation / damages

3) There must be an admission of guilt (having committed a criminal act) and a statement from the perpetrator

4) There must be an apology from the perpetrator and an apology from the victim or victim's family (mutual forgiveness)

5) It must be carried out by deliberation to reach a consensus between law enforcement officials, the perpetrator or the perpetrator's family, the victim or the victim's family.

Based on the above criteria, it is hoped that justice can be achieved, because there is a process of involving all parties in its resolution.

The ultimate goal of law is justice. Therefore, all efforts related to absolute law must be directed to find a legal system that is most suitable and in accordance with the principle of justice. Law must be closely intertwined with justice, law is a just law, if a concrete law, namely law is against the principles of justice, then the law is no longer normative and cannot be said to be law anymore. ${ }^{5}$

When humans agree on the existence of justice, then inevitably justice must color human behavior and life in relation to God, with fellow individuals, with society, with the government, with nature, and with other God's creatures. Justice must be realized in all lines of life, and every human product must contain the values of justice, because in fact unfair behavior and products will give birth to an imbalance, a mismatch that results in damage to

\footnotetext{
${ }^{1}$ Muhammad Syukri Albani Nasution, et. all, (2017), Hukum Dalam Pendekatan Filsafat, Jakarta: Kencana, p. 208.

${ }^{2}$ A.M. Syukri Akub and Sutiawati, (2018), Keadilan Restoratif (Restoratif Justice), Jakarta: Litera, p. 88-89

${ }^{3}$ Kadri Husin dan Budi Rizki Husin, (2016), Sistem Peradilan Pidana Di Indonesia, Jakarta: Sinar Grafika, p. 23

${ }^{4}$ Musakkir, (2011), Kajian Sosiologi Hukum Terhadap Penerapan Prinsip Keadilan Restoratif Dalam Penyelesaian Perkara Pidana, Jurnal Ilmu Hukum Amanna Gappa, Vol. 19 Nomor 3, p. 216-217

${ }^{5}$ Muhammad Syukri Albani Nasution, Op. Cit. p. 214
} 
both humans themselves and the universe. ${ }^{1}$

Justice must be realized, in order to be able to interpret the rule of law, eliminate legal impartiality and remain in the entity of justice. The law may have died if the spirit of the law, namely justice, was only wishful thinking, and in such circumstances the law was no longer conducive to justice seekers (justiabelen). Society as consumers of law can no longer enjoy the taste of justice so that people only get injustice. ${ }^{2}$

Law is an external manifestation of justice and justice is an authentic internal and spiritual essence of the form of law. Therefore the supremacy of law is the supremacy of justice and vice versa, both are commutative things. Law is not in the absolute dimension of law, but law is in the dimension of absolute justice. The law will not be able to survive if the spirit of justice has disappeared. As a result of the distortion of legal thinking with the loss of legal integrity, the law seems unable to become a means of producing justice. The components of the legal apparatus, such as producers of laws and regulations or law enforcers, have not been able to become justice producers, this is because producers of laws and regulations are unable to place justice as the spirit of legislation, and law enforcers themselves do not have high moral integrity. ${ }^{3}$ If the law is separated from the norms of justice, it is possible that the legal norms that are stipulated are unfair laws. ${ }^{4}$

If it is related to the settlement of criminal acts in the field of property by using the concept of diversion through the principle of restorative justice, then the concept of justice according to the concept of restorative justice is very relevant, because to get good and fair results it is necessary to conduct consensus by involving all parties concerned, namely victims, victims' families, perpetrators, and third parties in making decisions so that the decisions taken reflect the value and sense of justice for them. The disputing parties have free will to find a way to settle the case that can restore their rights, especially the victim. The victim gets his right back in the form of restitution of the losses he suffered as a result of the criminal act committed by the perpetrator and in fact the return of the loss what the victim wants, on the other hand, the perpetrator does not need to serve a prison sentence (corporal punishment) so that the dignity of himself and his family is maintained. The settlement process like this reflects justice. One thing is certain that the process of seeking justice does not solely belong to the state in the sense that justice is not solely provided by the state through its law enforcers but can also be carried out by the parties in the case by involving all interested parties to resolve the cases they face by way of deliberation to reach consensus that is born from the free will of the disputing parties.

In relation to the settlement of criminal acts through diversion using the principle of restorative justice, the realization of justice can be realized if from the aspect of the decision-making process it is actually carried out or implemented properly and correctly, for example in the form of involving all interested parties, namely victims, victims' families, the perpetrator, the perpetrator's family, third parties (religious leaders, colleagues, close family) and law enforcement officials (depending on the stage of the process) in the decision-making process.

The concept of Restorative Justice is a concept of thought that responds to the development of the criminal justice system by focusing on the needs by involving the community ${ }^{5}$, so that victims who are considered marginalized by the mechanisms that work in the current criminal justice system are involved in it. This theory is also a new frame of mind that can be used in responding to a crime in criminal law enforcement. ${ }^{6}$

The application of diversion with the principle of restorative justice in resolving criminal acts of property, basically applies substantive aspects (substantive truth) while still paying attention to procedural aspects (procedural truth) because in the process of resolving the case, it involves interested parties by upholding the rights and obligations of the parties (victims and perpetrators) by placing deliberation to reach consensus as the basic and main principle, this means the process means placing something in its place, imposing something according to one's bearing capacity, giving something that is due to one's right in a balanced degree, this is the essence of justice according to Islamic law.

Finally, justice based on the involvement of the victim, the victim's family, the perpetrator, the perpetrator's family, law enforcement officers or other third parties, whose decisions are based on the spirit of kinship in an atmosphere of deliberation with restoration and not retaliation, which becomes the spirit or moral strength of case resolution with the concept of diversion. through the principle of restorative justice, and that is true justice which is the hope of the victim, the victim's family and the perpetrator.

Thus the results achieved are ideal, proportional and fair for victims and perpetrators. Fairness is not only from the economic side in the form of giving compensation or returning goods that are the object of a criminal act but also from a psychological side because the settlement of a crime is taken in a dignified and civilized manner

\footnotetext{
${ }^{1}$ Sukarno Aburaera, (2006), Menakar Keadilan Dalam Hukum, Read out at the Admission Ceremony for Permanent Professor of Law at the Faculty of Law, Hasanuddin University Makassar, p. 2

${ }^{2}$ Ibid, p. 3

${ }^{3}$ Ibid, p. 4-5

${ }^{4}$ Sukarno Aburaera, (2012), Kekuasaan Kehakiman Indonesia, Makassar: Asia Timur, p. 153

${ }_{5}^{5}$ Timoera, D. A. (2014). Restorative Justice Dan Prospeknya Dalam Sistem Peradilan Pidana, Pidana Anak Di Indonesia. Jurnal Ilmiah Mimbar Demokrasi, 13(2), 79-92.

${ }^{6}$ Muhaimin, M. (2019). Restoratif Justice dalam Penyelesaian Tindak Pidana Ringan. Jurnal Penelitian Hukum De Jure, 19(2), 185-206.
} 
in accordance with the free and voluntary will of the victim and the perpetrator, besides that From the social point of view, a harmonious relationship is maintained and maintained between the victim and the perpetrator as well as his family, there is no resentment, hostility and conflict that can disrupt public security and order so that in the end there is balance and harmony and peace in society.

So justice is sincerity in accepting and or releasing what is due and giving people what is their right by placing something in accordance with its proportions so that balance and harmony are created in life.

\section{The manifestation of legal benefits for property crimes}

In law enforcement, especially criminal law, legal benefit is something that cannot be separated from utilitarian theory because criminal law enforcement has objectives based on certain benefits, and is not just retaliating against people who commit criminal acts, but has certain useful purposes. ${ }^{1}$

With regard to the purpose of punishment, with the utilitarian theory of Bentham says, that in all of itself punishment is evil (because it causes misery and pain), this is embraced by the principle of expediency, which should only be recognized if as far as possible the punishment will be negates that which is even worse. At the same time, the common goal of all laws is to increase the total happiness of society. Hence punishment must be beneficial in attaining a greater amount of pleasure and happiness, and punishment will have no justification if the consequences of that punishment will have justification if the consequences of that punishment still add more to the number of misery for society. The principle of benefit calls for the elimination of pure retribution, when a person is made to suffer just because that person's actions make the victim feel sick, then at that time the purpose of punishment has no more benefit by adding to the amount of misery to the whole of society. ${ }^{2}$

One of the benefits in relation to the discussion of this dissertation is the return of losses by the perpetrator to the victim, where the concept of victim loss in the integrated criminal justice system is not even considered, so is the process of recovering losses, for example, to claim the recovery of the victim's loss still has to take civil measures. by filing a lawsuit for default or actions against the law. Even though the victim's loss should get priority in the criminal justice system, this is in line with what Romli Atmasasmita said, which states that there is no criminal offense without a criminal act and no criminal act without harm. ${ }^{3}$

The concept of punishment built by the integrated criminal justice system as the purpose of punishment in relation to the criminal act of property basically does not provide benefits to the victim, because in fact the victim experiences material losses as a result of the perpetrator's actions and to restore and restore the rights of the missing victim is not imprison the perpetrator but returns the loss so that the victim can be recovered from the loss, either in the form of compensation or return of goods that are the object of the criminal act or in the form of loss of expected benefits, or reduced enjoyment of the property so that the victim can enjoy the lost material which in the end creating happiness for the victim and their family because they can enjoy their property that was lost due to the criminal act committed by the perpetrator. Compensation for damages is not solely in the form of material or immaterial but also in the form of returning goods which are the object of the criminal act.

Benefit is not only measured from the economic aspect in terms of compensation in the form of material to the victim by the perpetrator but also must be seen from the psychological aspect, for example providing inner peace for the victim, the victim's family, and the perpetrator. From the sociological aspect, for example, by achieving the resolution of the problem between the perpetrator and the victim by deliberation, consensus will strengthen ties (good relations) and provide peace because it does not cause prolonged disputes and benefits the community or the surrounding environment.

Ideally, (if it is related to the corrective justice put forward by Aristotle) the restitution of the loss to the victim should be able to recover the loss of the victim as a result of the actions committed by the perpetrator whether due to mistakes, deliberate actions, negligence, errors, defaults or acts against the law, meaning all forms of loss. suffered by the victim, whether material losses, immaterial, and even the expected benefits must be returned or restored to its original state, however this is very difficult to materialize, for example, it must be considered what caused the perpetrator to do this, what was the economic and psychological condition of the perpetrator when he committed the act. as well as at the time of recovering the loss. This is where deliberation and consensus play an important role based on forgiveness, goodwill, and honesty from the victim and the perpetrator. The parties (victims and perpetrators) interpret and practice the values of local wisdom which are crystallized in the Pancasila principles, including mutual respect and disregard for fellow human beings, an attitude of not imposing will on others, prioritizing deliberation to reach a consensus. overwhelmed by this familial spirit which is the basic essence or basic value of the character of the Indonesian nation in solving any problems faced by society or individuals. Victims with a large soul forgive the perpetrator to compensate the perpetrator in accordance with the ability of the perpetrator without harming the victim, likewise the perpetrator with mutual respect, acknowledgment and

\footnotetext{
${ }^{1}$ Syaiful Bakhri, (2009), Pidana Denda dan Korupsi, Yogyakarta: Total Media p. 129

2 Dwi Hananta, (2017), Menggapai Tujuan Pemidanaan Dalam Perkara Pencurian Ringan, Bandung: Mandar Maju, p. 13

${ }^{3}$ Tarigan, B. (2020). Polemik Pasal 3 Uu No. 31 Tahun 1999 Tentang Tipikor Mengenai Unsur Niat Jahat Dan Memperkaya Diri Bagi Pelaku

Tindak Pidana Korupsi. Jurnal Justiqa, 2(1), 27-39.
} 
respect for the rights of others.

One of the shortcomings in the integrated criminal justice system that has not been maximally regulated is punishment from an economic aspect (whether returns in material, immaterial, expected benefits, or returns of goods taken by the perpetrator in his criminal act), this is where the essential difference with the concept of diversion through the principle of restorative justice, where the concept of diversion through the principle of restorative justice emphasizes the return or recovery of losses to victims through deliberation to reach a consensus so that in the end it will be especially useful for victims and their families as well as for actors and society or the state. In other words, the benefit must be seen not only on the victim's side but also on the perpetrator, society or the state.

\section{The manifestation of legal certainty for property crimes}

Understanding According to Gustav Radbruch, there are two kinds of definitions of legal certainty, namely "legal certainty because of the law", and "legal certainty in or from the law". Laws that have succeeded in ensuring a lot of legal certainty in society are useful laws. ${ }^{1}$

Understanding According to Gustav Radbruch, there are two kinds of definitions of legal certainty, namely "legal certainty because of the law", and "legal certainty in or from the law". Laws that have succeeded in ensuring a lot of legal certainty in society are useful laws".

Without legal certainty, people do not know what to do and eventually unrest arises. However, too much emphasis on legal certainty, too strict obeying legal regulations will result in stiffness and will create a sense of unfairness. Whatever happens the rules are such and must be obeyed or implemented. Laws often feel cruel if they are strictly enforced: lex dura, sed tamen scripta (Laws are cruel, but they are true). As a result of the strict and rigid application of the law, the law itself provides room for movement in the form of discretion for law enforcement officials to take strategic steps to fulfill a sense of justice, benefit and legal certainty.

Legal certainty must bind the parties in dispute or litigation, in this case the victim and the perpetrator. The results of decisions made in a fair, balanced and equal deliberation and consensus process must provide certainty to the victim to get compensation both regarding the value (amount) to be obtained as well as the time and procedure and for the perpetrator must be clear and firm regarding the implementation of his obligations including the consequences law if the perpetrator does not carry out the diversion agreement so that the perpetrator can be accountable for his actions.

One of the aspects that require legal certainty, namely the regulation regarding compensation that must be provided by the perpetrator of a criminal act to the victim of a crime, the said regulation must be in the form of a law so that it has a legal umbrella, because the provision of compensation in the settlement of property crimes is based on the concept of diversion. Through restorative justice is a form of guarantee of legal protection and the responsibility of the perpetrator and the rights of the victim and is an important requirement in the said process. The arrangement for the provision of compensation in Article 98 of the Criminal Procedure Code is not strict, such as regarding the procedures or stages of providing compensation, there must be a request / request from the victim, the judge is bound by a decision that cannot exceed what is demanded / requested, the conditions that must be met by the victim to ask for compensation, compensation does not release the perpetrator from imprisonment.

As a concretization or a follow-up to decisions taken from the deliberation to reach a consensus, law enforcement officials as mediators in resolving criminal cases must make a conciliation report or agreement to be followed up by making a court order. That is a simple form of legal certainty in relation to settlement with the concept of diversion through restorative justice if the diversion process is successful, as well as if the diversion process fails, the legal certainty awaited by the disputing parties is the judge's decision which has permanent / definite legal force.

Legal certainty does not only include in-concrete law at the time of law enforcement and application. Legal certainty is also determined by the legal system in abstracto. Likewise, the judicial process is not the only final place to determine legal certainty. Thus it is clear that law enforcement in order to create legal certainty is not only the domain of the criminal justice system through the judiciary (in court) but can also be done through a case settlement mechanism outside the court on the condition that the process concerned must provide legal certainty to the victim, actors and society so that order and security can be realized.

Legal certainty must be a value for every party in every aspect of life, apart from the role of the state itself in implementing legislative and judicial laws. Everyone or parties are not allowed to behave arbitrarily. As a value, legal certainty is not always related to the state, because the essence of legal certainty is a matter of protection from arbitrary actions. Legal certainty is stipulated in statutory regulations that should protect judiciaries from arbitrary actions. However, when these statutory regulations are no longer in accordance with the development of society, then there tends to be arbitrariness towards justice in the form of neglect by the legislators, here the

\footnotetext{
${ }^{1}$ Ridwansyah, M. (2016). Mewujudkan keadilan, kepastian dan kemanfaatan hukum dalam qanun bendera dan lambang Aceh. Jurnal
} Konstitusi, 13(2), 278-298. 
antinomy of the value between justice and legal certainty emerges. The tension between the two elements also occurs in criminal acts that are economically relatively small in value of losses, on the one hand legal certainty requires that anyone who is proven to have committed a criminal act must be sentenced to a criminal equivalent to his actions, on the other hand the element of justice also requires judicial policy considering the small value of the victim's loss which is deemed incompatible with the threat of punishment. The court as an institution in charge of imposing crimes must be well aware of whether the (punishment) imposed has a positive impact on the convicted person or not. Therefore, the issue of imposing a sentence is not just a matter of the severity of the crime, but also whether the crime is effective or not, and whether the punishment is in accordance with the social, cultural and structural values that live and develop in society.

Legal certainty in settlement with the concept of diversion through the principle of restorative justice is manifested in the form of making minutes of deliberation results from the parties which contain the rights and obligations of the parties which are then followed up by the stipulation of a peace deed by the Judge / Court. This determination actually becomes the guideline and reference for victims and perpetrators to exercise their respective rights and obligations. This stipulation or decision becomes a law for victims and perpetrators so that it can provide a sense of calm and a sense of security (calm and security), especially for victims and or their families because there is certainty to have their rights lost or reduced due to criminal acts or criminal acts committed. by the perpetrator of a criminal act.

However, what is actually needed is legal certainty in the form of statutory instruments regarding the process, procedure and procedure for settlement with the concept of diversion through restorative justice, which is very much needed to meet the demands of a sense of legal certainty from the community, because in fact the practice of settlement with the concept of diversion already exists. and it has been practiced by the Indonesian people and has even crystallized the values of Pancasila as the source of all sources of law in Indonesia, but it has not been institutionalized in statutory regulations. The state, in this case the Government together with the People's Representative Council of the Republic of Indonesia (DPR RI), must be able to fulfill this sense of legal certainty by regulating it in statutory regulations.

\section{Conclusion}

The essence of solving property crimes with the concept of Diversion through the Restorative Justice approach is based on deliberation to reach a consensus by involving victims, perpetrators and their families, law enforcement officials and third parties. Deliberation is the spirit of the concept of diversion through the principle of restorative justice and is the gateway to the settlement of property crimes. In the deliberation process, the perpetrator and the victim and / or the victim's family will express their opinions and desires freely on an equal and balanced basis. In this way the perpetrator and the victim and / or the victim's family feel appreciated because there is involvement of the parties in decision making so that deliberation decisions reflect justice, benefit and legal certainty which are the essence of case resolution through the concept of Diversion.

\section{References}

A.M. Syukri Akub and Sutiawati, (2018), Keadilan Restoratif (Restoratif Justice), Jakarta: Litera.

Dwi Hananta, (2017), Menggapai Tujuan Pemidanaan Dalam Perkara Pencurian Ringan, Bandung: Mandar Maju.

Djisman Samosir, (1992), Fungsi Pidana Penjara dalam Sistem Pemidanaan Indonesia, Bandung: Bina Cipta.

E. Fernando M. Manulang, (2007), Menggapai Hukum Berkeadilan, Tinjauan Hukum Kodrat dan Antinomi Nilai, Jakarta: Kompas.

I Made Pasek Diantha, 2016, Metodologi Penelitian Hukum Normatif Dalam Justifikasi Teori Hukum, Jakarta: Prenadamedia Group.

Kadri Husin dan Budi Rizki Husin, (2016), Sistem Peradilan Pidana Di Indonesia, Jakarta: Sinar Grafika.

Muhadar, (2017), Lecture Material Doctor of Law Program in the Faculty of Law, Hasanuddin University Makassar.

Mukti Fajar \& Yulianto Achmad, (2010), Dualisme Penelitian Hukum Normatif \& Empiris, Yogyakarta: Pustaka Pelajar.

Muhammad Syukri Albani Nasution, et. all, (2017), Hukum Dalam Pendekatan Filsafat, Jakarta: Kencana.

Muhaimin, M. (2019). Restoratif Justice dalam Penyelesaian Tindak Pidana Ringan. Jurnal Penelitian Hukum De Jure, 19(2), 185-206.

Musakkir, (2011), Kajian Sosiologi Hukum Terhadap Penerapan Prinsip Keadilan Restoratif Dalam Penyelesaian Perkara Pidana, Jurnal Ilmu Hukum Amanna Gappa, Vol. 19 Nomor 3.

Nur, R., \& Bakhtiar, H. S. (2020). The Imposition of Sanctions for Children. Hasanuddin Law Review, 6(2), 165171.

Ridwansyah, M. (2016). Mewujudkan keadilan, kepastian dan kemanfaatan hukum dalam qanun bendera dan lambang Aceh. Jurnal Konstitusi, 13(2), 278-298. 
Sadjijono. (2014). Hukum Antara Sollen dan Sein (Dalam Perspektif Praktek Hukum di Indonesia). Surabaya: Ubhara Press \& LaksBang PRESSIndo.

Sukarno Aburaera, (2006), Menakar Keadilan Dalam Hukum, Read out at the Admission Ceremony for Permanent Professor of Law at the Faculty of Law, Hasanuddin University Makassar.

Sukarno Aburaera, (2012), Kekuasaan Kehakiman Indonesia, Makassar: Asia Timur.

Syaiful Bakhri, (2009), Pidana Denda dan Korupsi, Yogyakarta: Total Media.

Tarigan, B. (2020). Polemik Pasal 3 Uu No. 31 Tahun 1999 Tentang Tipikor Mengenai Unsur Niat Jahat Dan Memperkaya Diri Bagi Pelaku Tindak Pidana Korupsi. Jurnal Justiqa, 2(1), 27-39.

Timoera, D. A. (2014). Restorative Justice Dan Prospeknya Dalam Sistem Peradilan Pidana, Pidana Anak Di Indonesia. Jurnal Ilmiah Mimbar Demokrasi, 13(2), 79-92. 